\title{
Szerves- és mütrágyázás tartamhatása a talajaggregátumok stabilitására agyagbemosódásos barna erdőtalajon
}

\author{
DuNAI Attila és TóTH Zoltán \\ PE GK Növénytermesztéstani és Talajtani Tanszék, Keszthely
}

\section{Bevezetés}

A talajok aggregátum-stabilitása, mint a különböző talajdegradációs folyamatokkal szembeni ellenállás mértéke egyike a legfontosabb talajfizikai paramétereknek, és már hosszú idő óta a talajfizikával foglalkozó kutatások előterében áll (JOZEFACIUK \& CHACHOR, 2014). Maguk az aggregátumok elsődleges talajrészecskék csoportosulásának tekinthetők, amelyeken belül az egyes alkotórészek nagyobb erőkkel kötődnek egymáshoz, mint a körülöttük lévő egyéb talajrészecskékhez (NIMMO, 2013).

A talajok aggregátum-stabilitása számos tényezö függvénye. Az általánosan elfogadott elvek szerint a stabilitásra ható tényezőket két fő csoportra, belső és külső tényezőkre szokás osztani (AMEZKETA, 1999).

A belső tényezők között az egyik legfontosabb a talajok szervesanyag-tartalma (BARRAL et al., 1998; SAHA et al., 2011). Általánosságban elmondható, hogy a szerves anyag mennyiségének növekedésével nő a stabilitás, és a kisebb agyagtartalmú talajokban kifejezettebb a szerves anyag stabilitásra gyakorolt hatása. A szerves anyag stabilitásnövelő hatását két mechanizmus magyarázza: a szerves anyag mennyiségének növekedésével nő a hidrofobicitás, ezzel a vízzel szembeni ellenállás mértéke növekszik, másodsorban a növekvő szervesanyag-mennyiség több kémiai kötés létrejöttét teszi lehetővé az aggregátumok között, ami stabilitásnövelő hatású (CHENU, 2000). Fontos a szerves anyag időbeli bekerülése is: friss szerves anyag hozzáadásával nő a stabilitás a mikrobiális dekompozíción keresztül felszabaduló szerves vegyületek (pl. poliszacharidok) hatására. Ez a hatás ugyanakkor humuszfrakció függő: a labilis frakció hatása gyors, de többnyire rövid ideig tart (KAY, 1998), a stabilabb frakciók kisebb hatásúak, de a hatás tovább tart (MARTENS, 2000).

A szerves anyag egyes frakcióinak külön is lehet szerepük a stabilitásban. A 250-2000 $\mu \mathrm{m}$-es tartományba eső szervesanyag frakció (particulate organic matter, POM), és főleg annak szabad állapotú, „könnyü” frakciója (light fraction, LF) stabi-

Postai cím: DUNAI ATTILA, Pannon Egyetem, Georgikon Kar, Növénytermesztéstani és Talajtani Tanszék, 8360 Keszthely, Festetics u. 7.E-mail: dunai@georgikon.hu 
litásnövelő hatású. Ez az anyag egyfajta magként viselkedik a talajokban, amely a köré épülő anyagokkal makroaggregátumok kialakulását teszi lehetővé.

Az LF a talajokban az agyaggal és különböző polivalens kationokkal alakítja ki az aggregátumokat (JASTROW, 1996). A no-till művelési rendszerekben a stabilitás növekedése jórészt az LF-POM frakció növekedésének eredménye (SIX et al., 1999). A POM hatása ugyanakkor annak is köszönhető, hogy mikrobiális dekompozíciójával extracelluláris poliszacharidok képződnek, amelyek kötőanyagként viselkedve növelik a stabilitást (JASTROW, 1996).

A kationcserélő kapacitás (T-érték) mértéke szintén fontos tényező az aggregátum-stabilitás szempontjából - növekedésével általánosságban nő a stabilitás (TISDALL, 1996). A kicserélhető kationok között a monovalens $\mathrm{Na}^{+}$mennyiségének növekedése a stabilitást csökkenti. Hasonló hatású az ugyancsak monovalens $\mathrm{H}^{+}$ ionok nagy koncentrációja is.

Általánosságban elmondható, hogy az adszorbeált divalens ionok monovalens ionokra cserélése stabilitáscsökkentő hatású. Az olyan divalens ionok, mint a $\mathrm{Ca}^{2+}$ vagy az $\mathrm{Mg}^{2+}$ mennyiségének növekedése szerkezetjavító hatású; ugyanakkor a magnézium koncentráció növekedése stabilitáscsökkentő hatású is lehet az agyagdiszperzió eredményeként. A hatás mértéke az agyagásvány-összetétel és az elektrolit-koncentráció függvénye (ZHANG \& NORTON, 2002). A $\mathrm{Ca}^{2+}$ viszont az aggregátum-stabilitás mértékét növeli, mivel akadályozza a diszperziót, és lecserélheti a $\mathrm{Na}^{+}$-ot és a $\mathrm{Mg}^{2+}$-ot (ARMSTRONG \& TANTON, 1992). További pozitív hatás lehet az organominerális komplexekben kialakuló Ca-hidak stabilitásnövelő hatása (CHAN \& HEENAN, 1999).

A stabilitás mértékére jelentős hatást gyakorolnak a különböző agyagásványok is. Az 1:1-típusú agyagásványoknál, mint pl. a kaolinit, alacsonyabb T-érték és fajlagos felület mérhető, ami a stabilitáscsökkenés irányába mutat. A 2:1-típusú agyagásványok (pl. szmektitek) fajlagos felülete és ennek következtében az aggregátum-stabilitása is nagyobb lehet (AMEZKETA, 1999).

MAZURAK (1950) a nagy fajlagos felületủ agyagásványok, mint pl. a bentonit jelenléte mellett nagyobb stabilitás értékeket mért, mint a kisebb felületủ agyagásványok esetében. Megemlítendő ugyanakkor, hogy a duzzadó agyagásványok esetében a duzzadási és zsugorodási folyamatok befolyásolhatják a stabilitásváltozás irányát (növekedés-csökkenés) ill. mértékét - az agyagtartalom, valamint a duzzadási-zsugorodási ciklusok számának függvényében (PICCOLO et al., 1997).

A belső tényezők csoportjában találjuk a talajokban található vas-alumíniumoxidok (IGWE et al., 2009) és szeszkvioxidok szerepét is (KAY \& ANGERS, 1999). $\mathrm{Az}$ Al-humusz komplexek és a nemkristályos $\mathrm{Al}^{3+}$ hidroxidok jelenlétével is nő a stabilitás, azok közvetett hatásának eredményeként; ezek megvédik a talaj szerves széntartalmát a mikrobiális dekompozíciótól (OADES \& WATERS, 1991; DALAL \& BRIDGE, 1996).

A polivalens Al- és Fe-ionok kation-hidak létrehozásával is javítják a talajszerkezetet (AMEZKETA, 1999). Az oldható szilikátok mennyiségének növekedése szintén lehet stabilitásnövelő hatású; a nátrium-szilikátok talajhoz adása azonban cementálódást okoz (BAVER et al., 1972). 
Az aggregátumok stabilitására jelentős hatással van a talajok $\mathrm{pH}$-ja is. Magasabb pH-n és nagyobb mésztartalom mellett több nagyméretű makroaggregátum keletkezik (BOIX-FAYOS et al., 2001).

A mésztrágyázás okozta $\mathrm{pH}$-növekedés hatására javul a mikrobiális aktivitás, ami a stabilitás növekedését eredményezi (HAYNES \& NAIDU, 1998).

A fizikai féleség szintén meghatározza az aggregátumok képződését és stabilitását. Kisebb agyagtartalom mellett leginkább a szerves anyag mennyisége van hatással a szerkezet kialakulására. Az agyagtartalom növekedésével az agyag mennyisége és annak típusa már sokkal jelentősebb mértékben meghatározó (KAY, 1998).

A porozitás viszonyoknak közvetett hatása van a stabilitásra: a kis átméröjủ pórusok megvédik a talaj szerves C-tartalmát a dekompozíciótól (THOMSEN et al., 1999, 2003), míg a nagy átmérőjủ pórusok, amelyeket többnyire levegő tölt ki, a jobb $\mathrm{O}_{2}$-ellátottság miatt elősegítik a szerves szénvegyületek oxidációját.

A stabilitásra ható biológiai tényezők vizsgálatakor mindenképpen ki kell emelni a mikroorganizmusok szerepét (OADES, 1993; LADD et al., 1996). Általánosságban, a makroaggregátumok kialakulására inkább a talajlakó gombák aktivitása, míg a mikroaggregátumok képződésére a baktériumok vannak hatással (SCHUTTER \& DICK, 2002). A mikroorganizmusok által termelt kötőanyagok jelentősen növelik az aggregátumok stabilitását; Ezek közül megemlítendők a talajlakó gombák filamentumai (TISDALL, 1991), az arbuszkuláris mikorrhizából származó glomalin (WRIGHT et al., 1999), vagy az egyéb mikrobiális eredetủ extracelluláris poliszacharidok (ROBERSON et al., 1995). Ez utóbbiak erősen kötődnek az ásványi szemcsék felszínéhez és hidakat képeznek a szemcsék között (KAY, 1998; MARTENS, 2000). Bár hatásuk a stabilitás szempontjából nagyon jelentős, de nem tekinthető hosszú távúnak (KAY, 1998), mivel addig áll fenn, amíg a mikrobiológiai tevékenység aktív. Erre utal a „biológiai talajmüvelés” fogalma is, ami a talaj oly módon történő művelését, - tágabb értelemben használatát - jelenti, amellyel a talaj mikroorganizmusok számára a lehető legjobb körülmények megteremtését, a talajmủvelő eszközök segítségével létrehozott, agronómiai szempontból kívánatos talajállapot minél hosszabb idejü fennmaradása érdekében hoznak létre/alkalmaznak.

A biológiai tényezők között megemlítendő a talajlakó makroszervezetek szerepe is. A földigiliszták például biológiai és fizikokémiai folyamatokon keresztül növelik az aggregátumok stabilitását (BROWN et al., 2000), bár a hatás mértéke függ a fajtól, a szerves anyag formájától, és a talaj típusától egyaránt (WINSOME \& MCCOLL, 1998).

A termesztett növény faja is meghatározó az aggregátumok stabilitása szempontjából. Hatása a növényi maradványokból származó szerves anyagok mennyiségének és formájának függvénye. A kukorica vagy lucerna maradványokban például magasabb fenoltartalom mérhető, ami stabilitásnövelő hatású, ugyanakkor a szója alacsony fenoltartalma alacsonyabb stabilitást is eredményezhet (MARTENS, 2000).

A növényi maradványok kémiai tulajdonságain túl a gyökérrendszer morfológiai sajátosságai közvetetten szintén befolyásolhatják az aggregátumok stabilitását. A növényi gyökerek rizoszférája a kibocsátott exudátumok révén jelentős ragasztó hatást gyakorol a stabilitásra, növelve annak mértékét. Stabilizáló hatásuk mértéke a gyökérsürüséggel áll összefüggésben (RILLIG et al., 2002). 
Pillangós növények termesztésekor általában nagyobb stabilitás értékek mérhetők, a nagyobb mennyiségủ mikrobiális biomassza következményeként (CHAN \& HEENAN, 1996; HAYNES \& BEARE, 1997).

A talajok aggregátum-stabilitására ható külső tényezők közé elsősorban a klimatikus viszonyokat soroljuk, de ez magába foglalja többek között a talajmüvelés, a tápanyagellátás és ezen belül különösen a szerves- és mütrágyahasználat aggregátum-stabilitásra gyakorolt hatását is. A klimatikus viszonyok szerepe meghatározó a stabilitás szempontjából: a hatás iránya és mértéke is nagyon változó, a hőmérséklet és a nedvességtartalom függvényében alakul (száraz-nedves periódusok, fagyfelengedés folyamata, mikrobiális aktivitás hömérséklet függése stb.). Az aggregátum-stabilitást befolyásoló tényező a domborzat, a vizsgált terület elhelyezkedése, kitettsége és a lejtőszög is (BRYAN et al., 1989).

A különböző mủvelési módok (hagyományos, redukált, minimum, no-tillage) aggregátum-stabilitásra gyakorolt hatásait többen is vizsgálták (ALVARO-FUENTES et al., 2008).

SIX és munkatársai (1999) tapasztalatai szerint a hagyományos (szántásos) müvelés csökkentette az aggregátum-stabilitást a no-till rendszerhez képest. Ezen hatások tartamkísérletes vizsgálatára is találunk szakirodalmi példákat.

ANDRUSCHKEWITSCH és munkatársai (2014) két 23 és egy 18 éves kísérletben vizsgálták a különböző müvelési módok aggregátum-stabilitásra gyakorolt hatásait. Vizsgálataik során a művelt rétegben magasabb makroaggregátum-stabilitás értékeket mértek a redukált és no-till rendszerekben, mint a hagyományos (szántásos) müvelésben. Ezzel szemben a müvelés alatti talajrétegben a hagyományos müvelés negatív hatása nem volt kimutatható.

PAUL és munkatársai (2013) 10 éves kísérletben mérték a frakcionált aggregátum-stabilitás értékeket. Eredményeik szerint a müvelt rétegben a nagy- $(2 \mathrm{~mm}<)$ és a kisméretú $(250-2000 \mu \mathrm{m})$ makroaggregátum-frakció stabilitás értékei is magasabbak voltak a csökkentett menetszámú mủvelésben, mint a hagyományos müvelés esetében.

A talajok aggregátum-stabilitására jelentős hatást gyakorol a mütrágyázás is. A hatás nagymértékben mütrágyaforma- és adagfüggő, általánosságban a nagy adagú nitrogén műtrágyázás számos talajkémiai tulajdonságot megváltoztat, pl. a talajok pH-ja vagy a T-értéke csökken. Ha a kijuttatott $\mathrm{N}$-mütrágya monovalens ionokat, pl. $\mathrm{NH}_{4}{ }^{+}$-t tartalmaz, a nagy adagú kijuttatás a monovalens ionok túlsúlyát eredményezheti, ami peptizációhoz, ezzel a talajszerkezet romlásához, és végső soron a stabilitás csökkenéséhez vezet (TISDALE et al., 1993).

A foszfortrágyázás is hatással van a stabilitásra, jórészt azonban közvetett módon, mivel a gyökérnövekedésre és az arbuszkuláris mikorrhiza kolonizációra pozitívan hat (FACELLI \& FACELLI, 2002). A foszfor mütrágyázás az Al-Ca-foszfátok képződését segíti, amelyek stabilitásnövelő hatásúak (HAYNES \& NAIDU, 1998).

A nemzetközi szakirodalomban jó néhány példát találunk a különbözö szervesanyag-kiegészítések aggregátum-stabilitásra gyakorolt hatásának vizsgálatára. Ezek azonban többnyire vagy kontrollált körülmények között 7-336 napig tartó laboratóriumi inkubációs vizsgálatok (TRAORÉ et al., 2000 - glükóz, két hónap; LIU et al., 2005 - keményítő, két hónap; CosENTINO et al., 2006 - búzaszalma, 336 nap 
stb.), vagy szántóföldi körülmények közötti 3-60 hónapos kísérletek eredményeit mutatják be (DIAZ et al., 1994 - tőzeg, két év; SPACCINI et al., 2004 - kukorica és mustár növényi maradványok, három hónap stb.).

Ezen vizsgálatok eredményei alapján a szervesanyag-visszapótlás általában növeli a stabilitás értékeket a kezelésben nem részesüló területekéhez képest. A stabilitásnövelö hatás mértéke azonban a területre kijuttatott szerves anyag mennyiségének és minőségének függvénye (CHIVENGE et al., 2011).

A külső tényezők között megemlítendő még a mulcsanyagok stabilitásnövelö hatása is. A hatás közvetett, az erózió csökkenésén (LAYTON et al., 1993) és a szerves C-tartalom növelésén alapul (DUIKER \& LAL, 1999).

Maga az aggregátum-stabilitás számos talajfizikai paraméterre gyakorol hatást. Ilyen például a vízbeszivárgás (LE BissonNAIS et al., 2007), vagy például a talajok különböző eróziós hatásokkal szembeni ellenálló képessége (BAST et al., 2014).

Kisebb stabilitás értékek mellett nő az erózióra való hajlam. Ezen hatásokon kívül még számos egyéb tulajdonságot is befolyásol a stabilitás mértéke, így például a víz mozgását, a levegőzöttséget, közvetetten a biológiai folyamatokat (SIDDIKY et al., 2012), és végső soron a növények növekedését is (PICCOLO et al., 1997). Éppen ezért a talajok aggregátum-stabilitása különösen nagy jelentőséggel bír a mezőgazdaságilag hasznosított területeken, hiszen az aggregátumok stabilitásának nagyobb volta jobb talajszerkezetet eredményez, amely az említett tulajdonságok javitásán keresztül végső soron a talaj termékenységének növekedésében nyilvánul meg (PENG et al., 2004).

A talajok aggregátum-stabilitásának meghatározására számos módszer létezik. A módszerek közötti választást leggyakrabban a környezeti feltételek döntik el (BAST et al., 2015): száraz körülmények között, ahol a szél általi (deflációs) talajpusztulás jelentős lehet, a száraz aggregátum-stabilitás meghatározásának módszerei terjedtek el (BROERSMA et al., 1997). Ezzel szemben a csapadékosabb területeken, ahol az eróziós folyamatokat jórészt az esőzés és a felszíni elfolyás irányítja, a nedves stabilitás-meghatározási módszerek érvényesülnek (NIMMO, 2013). Az utóbbiak közül a leggyakrabban használt a nedves szitálásos módszer, melynek első változatát még YODER (1936) fejlesztette ki, így közel nyolcvan évre visszatekintő története van.

Hasonló alapelven működő módszereket nemzetközi (PAUL et al., 2013; SHAOSHAN et al., 2013) és magyar (DVORACSEK, 1957; KAZÓ, 1958; HUISZ, 2012) szerzök is alkalmaztak.

Ma a nedves szitálás módszertanában továbbra is a víz, és főleg ioncserélt vagy desztillált víz az alapvető folyadék; ugyanakkor pl. a frakcionált szitálás esetében a folyamatos átmosás miatt a fenti vízformák nem, vagy csak nehezen használhatóak. Ezért az ilyen vizsgálatokban csapvizet is használnak, ez azonban felveti az összehasonlíthatóság kérdését, ami miatt korrekciós tényezők használatára is szükség lehet. További folyadékként 96\%-os etil-alkohol jöhet szóba; ennek föleg az aggregátum-szétesés különböző formáinak (mechanikai hatások, duzzadás, diszperzió) elkülönítésében van szerepe (LE BISSONNAIS, 1996).

Az aggregátum-stabilitás alakulásában az idő is jelentős szerepet játszik. Különböző mintavételi időpontokban begyüjtött talajminták stabilitás értékei ugyanis jelentős eltéréseket mutathatnak; ennek elsősorban klimatikus, ill. a bekerülő szer- 
ves anyag lebomlásának dinamikájával kapcsolatos okai vannak. Ugyanakkor az azonos mintavételi időpontból származó minták aggregátum-stabilitás értékei is változnak a mintavételtől eltelt idő függvényében.

Az idő múlásával a makroaggregátumokat kialakító, pl. mikrobiológiai kötőanyagok lebomlanak, ezzel párhuzamosan a részecskék közötti fizikai kötőerők jelentősége megnövekszik. A mikrobiológiai kötőanyagok lebomlásának eredményeként bekövetkező szerkezetátalakulás az adhéziós és kohéziós erők növekedését vonja magával, ami az aggregátum-stabilitás növekedéséhez vezet (UTOMO \& DEXTER, 1981; KEMPER \& ROSENAU, 1984).

KEMPER és Koch (1966), BlaKe és Gilman (1970), ARYA és BlaKe (1972), ill. SCHWEIKLE és munkatársai (1974) is kimutatták a mintatárolási idő hatására történő aggregátum-stabilitás növekedést.

BARTLETT és JAMES (1980) tanulmányukban a szárítás és a tárolás hatásait vizsgálva szintén szerkezeti változásokról számoltak be.

A stabilitás értékek alakulásában a vizsgálat kivitelezési körülményeinek is van szerepe: a vizsgálati időtartam hosszának növekedésével csökken a stabilitás, elönedvesített mintákon pedig nagyobb stabilitás értékek mérhetők, mint a minták gyors nedvesítése után. Ennek magyarázata az, hogy a gyors nedvesítés eredményeként az aggregátumokba zárt levegő hirtelen távozik, ami szerkezeti károsodást okozhat, míg a lassú nedvesítéskor ilyen hatás nem jelentkezik (HUISz, 2012).

A talajok szerkezeti stabilitásának kialakításában a mikro- és makroaggregátumok egyaránt szerepet játszanak. A makroaggregátumok szerepe a jelentősebb, mivel a mikroaggregátumokra sokkal kevésbé hatnak a külső hatások, mint a makroaggregátumokra (SIX et al., 2000; BARBERA et al., 2012). A két kategória együttes vizsgálatára számos példát találunk a nemzetközi szakirodalomban (pl. ANNABI et al., 2011; BAST et al., 2015). Ezek a módszerek, bár számos járulékos információval szolgálnak a szerkezeti állapot megítéléséhez, nagymértékben laboridő- és anyagigényes megoldások. Emiatt már a múlt század hatvanas éveiben felmerült a nedves szitával végzett aggregátum-stabilitás vizsgálatok egyszerüsítésének gondolata. Az egyszerüsítési folyamatnak az egyik, később igen hatékonynak bizonyult iránya a frakcionált nedves szitáláshoz használt szitasorozat szitszámának redukálása.

Mivel a végső talajszerkezet kialakításában a makroaggregátumok szerepe jelentősebb, célszerủnek mutatkozott a makroaggregátum frakció további vizsgálata. Minthogy a két frakció határa 250 mikronnál van, ezért ilyen lyukátméröjü sziták használata a stabilitás vizsgálatok elvégzéséhez szükséges. Ezen gondolatsor alapján alakított ki KEMPER és KOCH (1966) egy máig is széles körben használt aggregátum-stabilitás vizsgálati módszertant, amely az 1 és $2 \mathrm{~mm}$ közötti talajfrakcióból 250 mikronos sziták segítségével határozza meg a makroaggregátumok stabilitását.

Az alapmódszert később KEMPER és ROSENAU (1986) fejlesztette tovább, kisebb módosítások pedig még a közelmúltban is történtek (pl. BLANCO-MOURE et al., 2012). A módszer jelenleg is széles körben használt, mivel a frakcionált nedves szitálásnál lényegesen gyorsabb, ill. azonos időtartam alatt jelentősen több minta vizsgálatát teszi lehetővé, mindezek mellett anyagigénye is kisebb. 
A módszerből származó eredmények elsősorban a gyakorlat számára nyújtanak hasznos információt a talajok állapotáról, de az alkalmazásával kapott stabilitás értékek tudományos kutatás alapját is képezhetik.

A nagyobb aggregátum-stabilitási értékek elérése és fenntartása alapvető fontosságú a talajtermékenység fenntartása és növelése, valamint a különböző degradációs folyamatok, így az erózió és számos egyéb, szerkezeti károsodást okozó folyamat hatásának csökkentése miatt. Mezőgazdasági szempontból az eróziós hatások mellett leginkább a talajművelés, ill. annak csökkentése vagy elhagyása, valamint a szervesanyag-tartalom befolyásolásán keresztül a különböző formájú és típusú trágyázási rendszereknek lehet befolyásoló szerepük az aggregátum-stabilitás mértékére. A fenti hatásokat célszerủ hosszú távú tartamkísérletekben tanulmányozni, mivel ezek megbízható forrást jelentenek az egyes kezelések hosszabb távú hatásainak vizsgálatához.

A hazai és nemzetközi szakirodalomban ugyanakkor kevés példát találni a különböző szervesanyag-kiegészítések (pl. istállótrágya-kijuttatás, komposztanyagok, zöldtrágya-növények) makroaggregátum-stabilitásra gyakorolt hatásainak hosszú távú tartamkísérletekben történő vizsgálatára.

AOYAMA és munkatársai (1999) a kanadai Quebec-ben 18 éves tartamkísérletben vizsgálták a szervestrágya-kiegészítés $\left(20 \mathrm{t} \cdot \mathrm{ha}^{-1} \mathrm{é}^{-1}\right.$ szarvasmarha trágya) hatásait az aggregátumok stabilitására. Eredményeik szerint az istállótrágya alkalmazása jelentősen növelte a stabil makroaggregátumok mennyiségét.

Hazánkban HUISZ (2012) végzett ilyen jellegü vizsgálatokat, amelyekben a szervesanyag-kiegészítés stabilitást növelő hatását tapasztalta $210 \mathrm{~kg} \mathrm{~N} \cdot \mathrm{ha}^{-1}$ műtrágya kijuttatás mellett.

Vizsgálataink során egy 30 éves szervestrágyázási tartamkísérlet különböző kezelésű parcelláinak nedves szitálásos módszerrel végzett makroaggregátumstabilitását határoztuk meg abból a célból, hogy megállapítsuk, van-e a szervestrágya-kiegészítéseknek, ill. a különböző $\mathrm{N}$-adagoknak szignifikáns hatásuk a talajstabilitás alakulására. Vizsgáltuk, hogy - amennyiben a kezelések hatására tapasztalható stabilitásváltozás - milyen a hatás jellege, mértéke, van-e a különböző kezelések között kölcsönhatás, ill. a kísérleti kezelések közvetett hatásai (pl. T-érték vagy a $\mathrm{pH}$ megváltozása) milyen módon és mértékben befolyásolják a talajaggregátumok stabilitását.

A szakirodalomban több, ellentmondó kutatási eredmény található arra vonatkozóan, hogy a különböző szerves trágyák, ezek között is föként az istállótrágya milyen hatást gyakorol a talaj szerkezeti állapotára.

Jelen vizsgálatunkban célul tüztük ki az istállótrágya alkalmazásának a tágabb értelemben vett talajtermékenységre, és ezen belül a makroaggregátumok stabilitására gyakorolt hatásának a termőhelyi körülmények között tapasztalható értékelésére a tartamkísérlet megbízható adat bázisán.

Termőhelyi körülmények között jellemezni akartuk a magasabb $\mathrm{N}$-adagok hatására fellépő esetleges peptizáció okozta szerkezetstabilitás csökkenés előfordulását, ill. annak mértékét. 
Mindezek mellett célul tüztük annak vizsgálatát, hogy a minták légszáraz állapotban tárolásának hatására a szakirodalomban közöltekkel egyezően növekszik-e a szerkezetstabilitás mértéke.

\section{Anyag és módszer}

Az aggregátum-stabilitás vizsgálatokhoz talajmintákat az 1983-ban Keszthelyen beállított, Nemzetközi Szerves- és Mütrágyázási Tartamkísérletből (Internationale Organische Stickstoff-dauerdüngungsversuch, IOSDV) gyüjtöttük.

A kísérlet kéttényezős, sávos elrendezésű három növényből álló gabonás vetésforgót (őszi árpa, kukorica és őszi búza) foglal magába (parcellaméret: $48 \mathrm{~m}^{2}$ ). A kísérletben szereplő egyik tényezőt a szervestrágya-kiegészítések, a másikat pedig az ekvidisztánsan növekvő nitrogén-adagok alkotják.

A szervestrágya-kiegészítésekből a kísérlet összesen három kezelést tartalmaz. Egy kezelés a mütrágya önmagában történő kijuttatása, ez jelenti a szervestrágyakiegészítés nélküli kontrollt. A másik kezelés 35 t·ha ${ }^{-1}$ adagban kijuttatott istállótrágya (mütrágya+istállótrágya, a továbbiakban IST), melynek kijuttatására a rotáció során egy alkalommal, háromévente a kukorica növény elött került sor. A harmadik kezelés (a továbbiakban NPK+Sz+ZT) a keletkező növényi maradványok alászántását foglalja magába $(\mathrm{Sz})$, a rotáció során egy alkalommal, háromévente egyszer az őszi árpa növény tarlójába zöldtrágya (ZT) növényt (olajretket) is elvetettek. A zöldtrágyát leszántották az árpa növényi maradványokkal. Ebben a kezelés ben a növényi maradványok lebontását elösegítendő, 1 t szármaradványra számított $10 \mathrm{~kg}$ $\mathrm{N}$-hatóanyagkiegészítés is volt hektáronként és évenként.

A kísérlet másik tényezőjét az ekvidisztánsan kiadott nitrogén mütrágyák jelentik. Az adagolás növénytöl függően történik; a kukorica esetében 0, 70, 140, 210 és $280 \mathrm{~kg} \cdot \mathrm{ha}^{-1}$, az őszi búza esetében $0,50,100,150$ és $200 \mathrm{~kg} \cdot \mathrm{ha}^{-1}$, míg az öszi árpa esetében $0,40,80,120$ és $160 \mathrm{~kg} \cdot \mathrm{ha}^{-1}$ a kijuttatott nitrogén hatóanyag mennyisége.

A P- és K-mütrágyázást tekintve minden parcella egységesen $100-100 \mathrm{~kg} \cdot \mathrm{ha}^{-1}$ $\mathrm{P}_{2} \mathrm{O}_{5}$ és $\mathrm{K}_{2} \mathrm{O}$ hatóanyag-tartalmú alapmütrágyázásban részesül. A kísérletben alkalmazott mütrágyakezelésekben a nitrogént Pétisó $(27 \% \mathrm{~N})$, a foszfort szuperfoszfát $\left(18 \% \mathrm{P}_{2} \mathrm{O}_{5}\right)$, a káliumot pedig kálisó $\left(60 \% \mathrm{~K}_{2} \mathrm{O}\right)$ formájában juttattuk ki. A kísérletet három ismétlésben állítottuk be, a parcellák száma: 3 szervestrágyakiegészítés x 5 nitrogén adag x 3 ismétlés x 3 növény $=135$ parcella.

A kísérlet talajtípusa agyagbemosódásos barna erdőtalaj, humuszban és foszforban gyengén, káliummal közepesen ellátott. Átlagosan a humusztartalom 1,6-1,7\%, az ammóniumlaktát oldható $\mathrm{P}_{2} \mathrm{O}_{5}$-tartalom $60-80 \mathrm{mg} \cdot \mathrm{kg}^{-1}$, a $\mathrm{K}_{2} \mathrm{O}$-tartalom $140-160$ $\mathrm{mg} \cdot \mathrm{kg}^{-1}$, a $\mathrm{pH}(\mathrm{KCl}) 6,8-7,0$ és a talaj fizikai félesége homokos vályog. Az évi átlagos csapadék összeg 683 mm (100 éves átlag), az évi középhőmérséklet $10,8{ }^{\circ} \mathrm{C}$.

Az aggregátum-stabilitás vizsgálathoz szükséges talajmintákat a kísérlet kukorica jelzőnövényü parcelláiból 2014. május elején, a kukorica kelése után vettük. Az összes parcellát megmintáztuk. A mintákat kézi ásó segítségével, a felső 25 centiméteres (müvelt) rétegböl gyüjtöttük. 
Parcellánként három részmintát vettünk, majd ezeket egyesítettük, ezek egy mintát képeztek a későbbi vizsgálatokhoz. A mintákat laboratóriumba szállítottuk, majd kézzel azonnal óvatosan kisebb darabokra tördeltük, végül nagy felületủ müanyag edényekbe helyeztük. A mintákat a légszáraz állapot eléréséig hagytuk az edényekben.

Ezt követően a mintákat Retsch AS200 Digit típusú szitarázó gépen 1 és $2 \mathrm{~mm}$ es sziták segítségével átszitáltuk, a gépet $1 \mathrm{~mm}$-es amplitudóval, öt percig járatva. Az aggregátum-stabilitás vizsgálatainkhoz a $2 \mathrm{~mm}$-es szitán átesett, de az $1 \mathrm{~mm}$-es szitán fennmaradt frakciót használtuk.

Az előkészítés során átszitált, légszáraz állapotú 1-2 mm-es talajfrakció aggregátum-stabilitás vizsgálatát nedves szitálással, az Eijkelkamp cég (Hollandia) „Wet Sieving Apparatus" (továbbiakban: WSA) készülékével végeztük. Ez a készülék az eredeti Kemper-Koch eljárás alapján készült. 8 db, $250 \mu \mathrm{m}$-es lyukméretü, kivehető szitát tartalmaz, melyekre egyszerre maximálisan kb. 6-8 gramm talajminta helyezhetö. A készülék 34/perces ütemmel dolgozik, teljes lökethossza $13 \mathrm{~mm}$. A vizes fázis a vizsgálat teljes időtartama alatt álló helyzetben marad, a talajminták pedig a szitákkal együtt mozogva merülnek bele és emelkednek ki az álló vízfázisból.

Vizsgálatainkhoz az eredeti ajánlásoknak megfelelően minden esetben $4 \mathrm{~g}$ mintát mértünk be analitikai mérlegen, majd maradék nélkül átvittük a szitákra. A gépet öt percig járattuk, majd egy perces lecsöpögési idő után a mintákat ioncserélt vízzel maradékmentesen bemostuk 100 ml-es, ismert tömegü fözőpoharakba. A mintákat $105^{\circ} \mathrm{C}$-on tömegállandóságig szárítottuk, majd analitikai mérlegen visszamértük. A kapott értékekből az edény üres tömegét levonva megkaptuk a stabil aggregátumfrakció és a hasonló méretủ, de nem aggregátum anyagok (homok) együttes tömegét.

A visszamérést követően a talajmintákat két órán át $0,1 \mathrm{M}$ Na-pirofoszfát oldattal kezeltük - az aggregátumok elroncsolása céljából -, majd az oldattal együtt maradék nélkül visszamostuk a szitákra és ismét öt percig szitáltuk. A szitákon fennmaradt frakciót visszamostuk a megfelelő főzőpohárba, majd $105^{\circ} \mathrm{C}$-on tömegállandóságig szárítottuk. Az edényeket ezután analitikai mérlegen visszamértük. Az edény üres tömegét levonva megkaptuk a 250 mikronos szitán fennmaradt, nemaggregátum frakciót (,homokkorrekció”).

A stabil aggregátum frakció százalékos arányát a következő képlettel számítottuk (CARON et al., 1992; VILLAR et al., 2004):

$$
\text { Stabil aggregátum }[\%]=\frac{\text { stabil frakció }(g r)-\text { homok frakció }(g r)}{\text { bemért talaj }(g r)-\text { homok frakció }(g r)} \times 100
$$

A stabil aggregátumok mennyiségének meghatározását elöször a minták begyüjtése után két héttel végeztük, majd az aggregátum-stabilitás értékek esetleges változásának meghatározása céljából a mintavételt követő három hónap elteltével újra vizsgáltuk ugyanezen a mintasoron. 
Az eredmények értékeléséhez az SPSS 15.0 statisztikai programcsomagot használtuk. A kezeléshatások kimutatására kéttényezős varianciaanalízist t-próbával, ill. ezt követően LSD Post-hoc tesztet alkalmaztunk.

\section{Eredmé nyek}

A mintavétel után két héttel elvégzett aggregátum-stabilitás vizsgálatok eredményeit az 1A. és 1B. ábrák, ill. az 1. táblázat mutatják be.

A

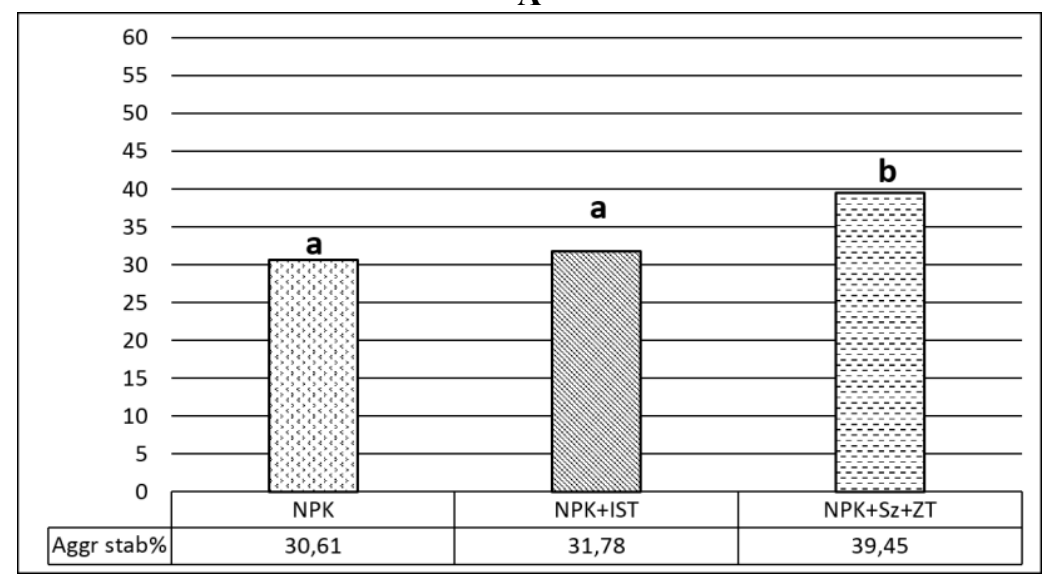

B

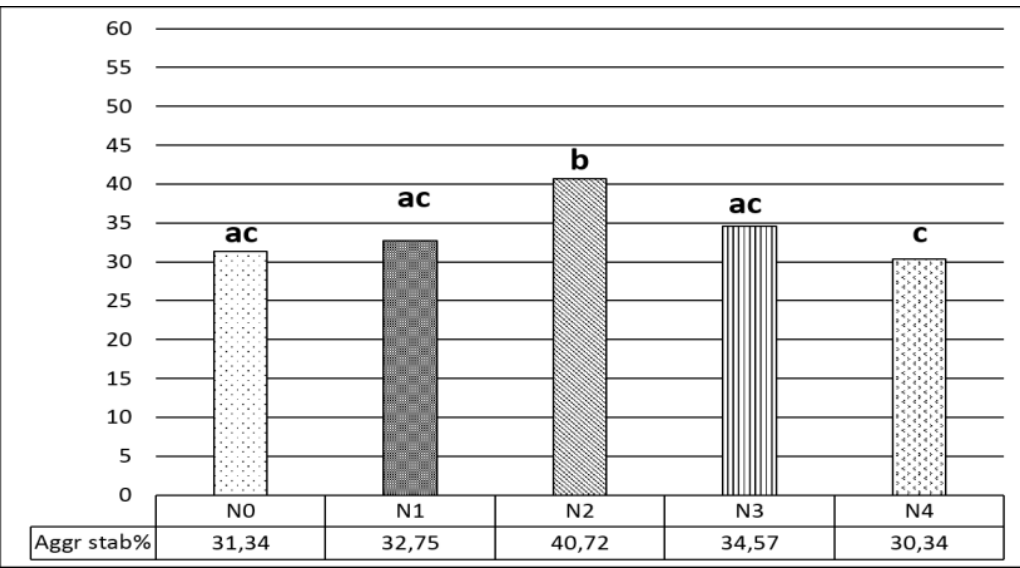

1. ábra

A két hetes mintákból származó aggregátum-stabilitás értékek (\%) (A) a szervestrágyakiegészítési módok szerint, a N-ellátás átlagában; (B) a N-adagok szerint, a szervestrágyakiegészítési módok átlagában. A különböző betűk az LSD Post-hoc teszt alapján szignifikáns különbségeket jelentik $(\mathrm{p}<0,05)$. 
Az 1A. ábrán a szervestrágya-kiegészítések szerinti stabilitás értékek láthatóak, százalékban kifejezve. Megállapítható, hogy a vizsgálat időszakában a növényi maradványok leszántása és a zöldtrágyázás kezelésben mintegy 9\%-kal nagyobb makroaggregátum-stabilitás volt mérhető a szervestrágya-kiegészítésben nem részesült parcellákéhoz képest. Megállapítható továbbá, hogy a NPK+Sz+ZT kezelés előnyösen hat a talaj aggregátumok stabilitására az istállótrágyázott kezeléshez képest. A kezelések közötti makroaggregátum-stabilitásbeli eltérés hasonló mértékü, azaz $8 \%$ volt. Az LSD Post-hoc teszt alapján az NPK+Sz+ZT kezelésben mérhető aggregátum-stabilitások szignifikánsan magasabbak a másik két kezelésben mérteknél.

Az 1B. ábrán a N-ellátottság szerinti aggregátum-stabilitás értékek láthatók, a szervestrágyázási módok átlagában. A vizsgálati eredmények alapján megállapítható, hogy a legnagyobb stabilitás értékek az N2-es, $140 \mathrm{~kg} \cdot \mathrm{ha}^{-1}$ nitrogénadag kezelésben voltak. A különbség a többi adaghoz viszonyítva 6-10\%-os; a legnagyobb eltérést ettől az N0 kontroll, ill. a legnagyobb N-ellátottság esetében tapasztaltuk. Az LSD Post-hoc teszt alapján az N2-es kezelésben mért érték szignifikánsan különbözik minden más N-kezelés stabilitás értékétől.

$\mathrm{Az}$ 1. táblázatban láthatóak a szervestrágya-kiegészítések és a $\mathrm{N}$-adagok kombinációiban mért aggregátum-stabilitás értékek. A legkisebb stabilitás értéket a csak mütrágyázott kontrollban mértük, ahol mindössze $23 \%$ volt a stabil aggregátumok aránya. A legnagyobb mért érték közel $51 \%(\mathrm{NPK}+\mathrm{Sz}+\mathrm{ZT} \mathrm{N} 2)$, ami több mint a kétszerese a legkisebbnek. A csak mütrágyázott kezelésben az N2-es nitrogénadag mellett mértük a legnagyobb stabilitás értéket $(\sim 38 \%)$, ami majdnem $15 \%$-al volt nagyobb az N0 kontrollénál. Ez a különbség statisztikailag igazolható $(p<0,05)$, akárcsak az N1 és az N4 adagok esetében, amelyek 9-9\%-kal voltak stabilabbak. Az istállótrágyázott változatban a legnagyobb stabilitás értéket az N1 nitrogénadagú ( $39 \%$ ), míg a legalacsonyabb értéket az N4 kezelésben mértük (24\%). A különbség statisztikailag igazolható, akárcsak az N3 adaghoz képesti stabilitás érték (27\%). Az NPK+Sz+ZT kezelésekben a másik két szervestrágya-kezelés vonatkozó értékeinél az N1-es nitrogénadagot leszámítva minden N-kezelésben nagyobb stabilitás értékeket mértünk.

\section{1. táblázat}

A két hetes mintákból származó aggregátum-stabilitás értékek (\%) a különböző szervestrágya-kiegészítési módok és $\mathrm{N}$-adagok szerint.

\begin{tabular}{|c|c|c|c|c|c|c|}
\hline \multirow{3}{*}{$\begin{array}{l}\text { (2) } \\
\text { Szervestrágya- } \\
\text { kiegészítés }\end{array}$} & \multicolumn{6}{|c|}{$\begin{array}{c}(1) \\
\text { Aggregátum-stabilitás, \% }\end{array}$} \\
\hline & \multicolumn{5}{|c|}{$\begin{array}{c}\text { (3) } \\
\text { N-trágyázás, } \mathrm{kg} \cdot \mathrm{ha}^{-1}\end{array}$} & \multirow{2}{*}{$\begin{array}{l}(4) \\
\text { SzD5 }\end{array}$} \\
\hline & $\begin{array}{c}0 \\
\text { (N0) }\end{array}$ & $\begin{array}{c}70 \\
(\mathrm{~N} 1)\end{array}$ & $\begin{array}{l}140 \\
\text { (N2) }\end{array}$ & $\begin{array}{l}210 \\
\text { (N3) }\end{array}$ & $\begin{array}{l}280 \\
\text { (N4) }\end{array}$ & \\
\hline a) NPK & 23,32 & 32,35 & 37,69 & 27,35 & 32,34 & \multirow{3}{*}{6,19} \\
\hline b) NPK+IST & 34,84 & 38,74 & 33,70 & 27,34 & 24,26 & \\
\hline c) $\mathrm{NPK}+\mathrm{Sz}+\mathrm{ZT}$ & 35,86 & 27,16 & 50,78 & 49,02 & 34,42 & \\
\hline
\end{tabular}


A különbségek különösen az N2 és N3-as nitrogénadagú kezelésekben jelentösek (13-22\%). Az N1 kezelésben mért érték ugyanakkor jelentősen kisebb a másik két $\mathrm{N} 1$ változaténál $(5$, ill. $11 \%)$.

A 2A. ábra a mintavétel után három hónappal elvégzett stabilitás vizsgálat eredményeit mutatja be a szervestrágyázási változatok szerint. A stabilitás értékek a 12 hetes, légszáraz állapotban történő tárolás alatt nagyjából kiegyenlítődtek, ugyanakkor itt is az NPK+Sz+ZT kezelésben mértük a legnagyobb aggregátumstabilitás értékeket, a különbség csak 1,5, ill. 1\%.

A

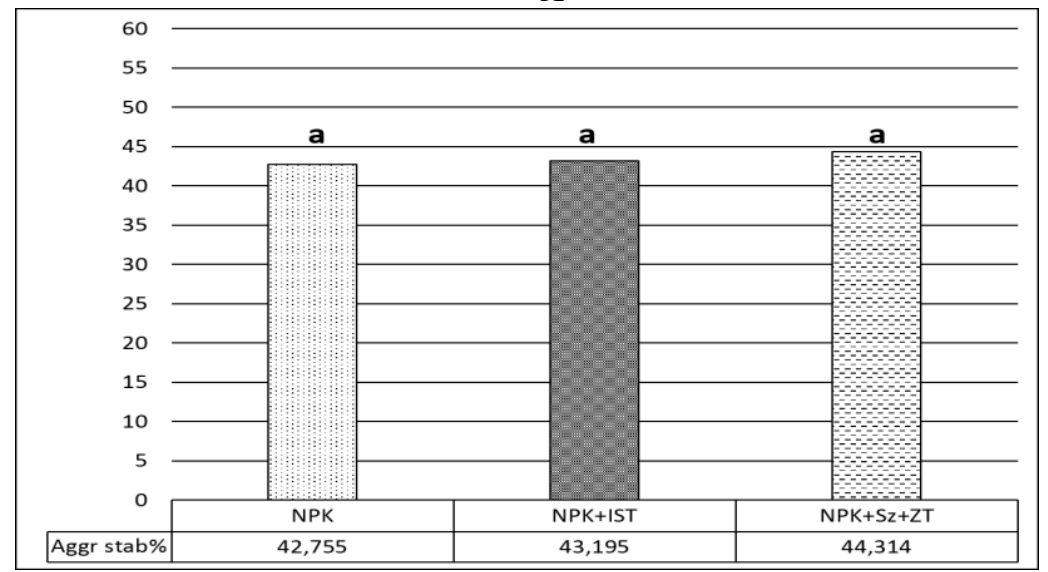

B

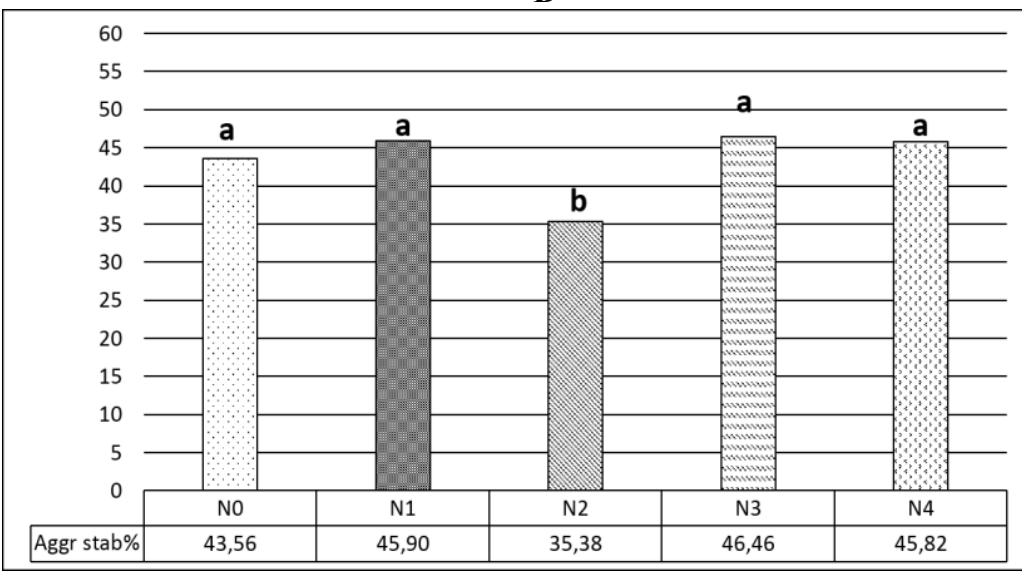

2. ábra

A 3 hónapos mintákból származó aggregátum-stabilitás értékek (\%) (A) a szervestrágyakiegészítési módok szerint, az N-ellátás átlagában; (B) a N-adagok szerint, a szervestrágyakiegészítési módok átlagában. A különböző betük az LSD Post-hoc teszt alapján szignifikáns különbségeket jelentik $(\mathrm{p}<0,05)$. 
A 2B. ábrán a három hónapos mintákon végzett vizsgálatok eredményeit ábrázoltuk N-ellátottság szerint. A két hetes vizsgálatok eredményeihez képest az N2-es frakció stabilitás-értékei jelentős csökkentek az összes többi N-adaghoz képest: a csökkenés mértéke 8-11\%-os, az LSD Post-hoc teszt alapján az N2-es kezelés értékei szignifikánsan kisebbek minden más $\mathrm{N}$-kezelésben mértnél.

A 2. táblázatban az egyes szervestrágya-kiegészitések és N-adagok kombinációiban mért aggregátum-stabilitás értékeket mutatjuk be a három hónapos mintasoron meghatározva. A szervestrágya-kiegészítési változatok mindegyikénél látható az N2-es nitrogénellátás melletti stabilitáscsökkenés. Mindhárom kezelésben e nitrogénadagú kezelében mértük a legkisebb stabilitás értékeket. A szerves trágyával kiegészített változatok N2 adagú stabilitás értékei 5, ill. 6\%-kal nagyobbak a csak mütrágyázott kezelés értékénél.

\section{2. táblázat}

A három hónapos mintákból származó aggregátum-stabilitás értékek (\%) a különböző szervestrágya-kiegészítési módok és a $\mathrm{N}$-adagok szerint.

\begin{tabular}{|c|c|c|c|c|c|c|}
\hline \multirow{3}{*}{$\begin{array}{l}\text { (2) } \\
\text { Szervestrágya- } \\
\text { kiegészítés }\end{array}$} & \multicolumn{6}{|c|}{$\begin{array}{c}(1) \\
\text { Aggregátum-stabilitás, \% }\end{array}$} \\
\hline & \multicolumn{5}{|c|}{ N-trágyázás, $\mathrm{kg} \cdot \mathrm{ha}^{-1}$} & \multirow{2}{*}{$\stackrel{(4)}{\mathrm{SzD} 5 \%}$} \\
\hline & $\begin{array}{c}0 \\
\text { (N0) }\end{array}$ & $\begin{array}{c}70 \\
(\mathrm{~N} 1)\end{array}$ & $\begin{array}{l}140 \\
(\mathrm{~N} 2)\end{array}$ & $\begin{array}{l}210 \\
(\mathrm{~N} 3)\end{array}$ & $\begin{array}{l}280 \\
(\mathrm{~N} 4)\end{array}$ & \\
\hline a) NPK & 42,93 & 49,58 & 31,94 & 42,36 & 46,97 & \multirow{3}{*}{ ns } \\
\hline b) NPK+IST & 39,86 & 41,40 & 36,91 & 45,44 & 52,37 & \\
\hline c) $\mathrm{NPK}+\mathrm{Sz}+\mathrm{ZT}$ & 47,88 & 46,72 & 37,29 & 51,58 & 38,11 & \\
\hline
\end{tabular}

Megjegyzés: ns nem szignifikáns

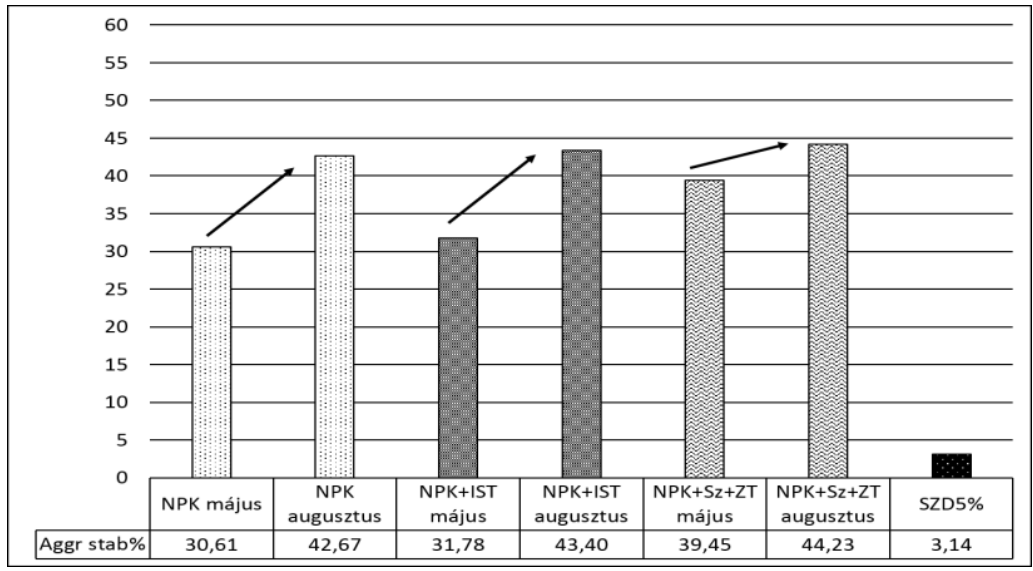

3. ábra

A mért aggregátum-stabilitás értékek időbeli változása a szervestrágya-kiegészítések szerint, a N-ellátás átlagában 


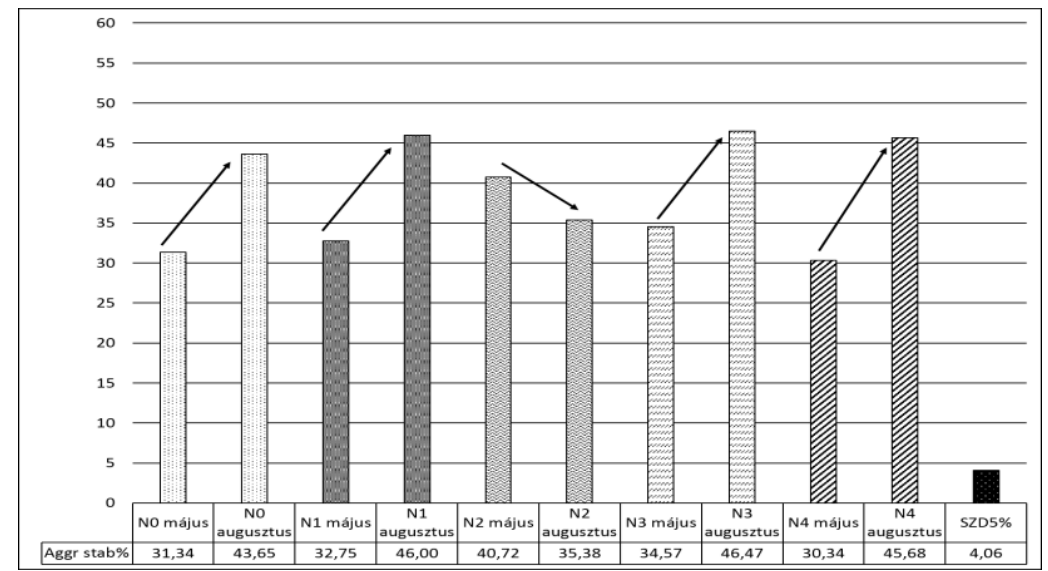

4. ábra

A mért aggregátum-stabilitás értékek időbeli változása a $\mathrm{N}$-adagok szerint, a szervestrágyakiegészítési módok átlagában.

Az aggregátum-stabilitás értékek időbeli változását a szervestrágyakiegészítések, ill. a N-adagok átlagában összefoglalóan a 3. és 4. ábrán mutatjuk be. A szervestrágya-kiegészítés szerinti bontásban minden változatban növekedés figyelhető meg a tárolási idő elörehaladtával. Az NPK ill. NPK+IST változatokban ez kifejezettebb (12-12\%), az NPK+Sz+ZT változatban kisebb (5\%), ugyanakkor a növekedés mértéke minden esetben szignifikáns. A $\mathrm{N}$-adagokat összehasonlítva megállapítható, hogy az N2-es kezelést kivéve mindenütt jelentős mértékű stabilitásnövekedés figyelhető meg (12-15\%). A különbségek statisztikailag igazolhatók $(\mathrm{p}<0,05)$. Az N2 kezelés esetében a csökkenés mértéke $5 \%$, a különbség pedig szignifikáns.

\section{Eredmények értékelése}

A mintavétel után két héttel mért aggregátum-stabilitás értékek általában kisebbek voltak, mint a mintavétel után három hónappal végzett vizsgálatokban mértek.

A mintavétel után két héttel a stabil aggregátumok aránya 23,3 és 50,8\% között, míg a mintavétel után három hónappal 31,9 és 52,4\% között változott.

A természetes körülmények között fennálló pillanatnyi talajállapot jellemzésére a mintavétel időpontjához közelebbi vizsgálat eredménye használható, mivel ilyenkor még érvényesül a talajokba kerülő, mikrobiális eredetű kötőanyagok hatása.

A szervesanyag-visszapótlás hatása is a mintavétel után két héttel elvégzett vizsgálatok esetében volt jelentős. A szármaradványok és a zöldtrágya visszaforgatásának eredményeként az aggregátum-stabilitás szignifikánsan nagyobbak voltak a tisztán mütrágyázott kontroll és az istállótrágyával kiegészített kezelésekhez viszonyítva. 
A szármaradvány-visszaforgatás kedvező hatásának magyarázata az lehet, hogy a plusz szubsztrátok a mikroorganizmusok számáramegnövelik az aktív mikrobiális tevékenység idejét és ezáltal a szerves kötőanyagok, pl. poliszacharidok mennyiségét (SCHLECHT-PIETSCH et al., 1994).

WANG és munkatársai (2011) is kimutatták a szármaradványok visszaforgatásának stabilitásnövelö hatását. Ugyanezt az eredményt kapták LONG és munkatársai (2015) is. Hasonló hatásra számíthatnánk az istállótrágyázás esetében is, ahogy, pl. ZALLER \& KÖPKE (2004). Azonban több szerző is felhívja a figyelmet az istállótrágyázás talajstabilitást csökkentő hatásaira (MBAGWU 1989; PARE et al., 1999).

A várt stabilitásnövelő hatás elmaradása az istállótrágyában megtalálható, diszpergáló hatású anyagok stabilitást csökkentő hatásával magyarázható. Ezt a hatást írta le például WHALEN és CHANG (2002), akik 25 éves kísérletben, évente 30 $\mathrm{t} \cdot \mathrm{ha}^{-1}$ adagban kijuttatott istállótrágyázás hatására lényegesen kisebb makroaggregátum-stabilitást mértek. Az alacsonyabb stabilitás-értékek okaként a trágyában található diszpergáló hatású anyagokat jelölték meg.

Az eredmények felhívják a figyelmet arra, hogy a szántóföldi melléktermékek visszaforgatásával nem csak a tápanyag-gazdálkodásban érhetünk el előnyöket, hanem a talajfizikai állapot kedvező befolyásolával a víz- és levegőgazdálkodáson keresztül a talajbiológiai folyamatokon át a tápanyag-körforgalomig élvezhetjük előnyeit, melyek a nagyobb és stabilabb termésszintek formájában tükröződnek vissza.

A kísérletben mért terméseredmények is ezt támasztják alá, mivel a szervesanyag kiegészítés kedvező hatása a nagyobb $\mathrm{N}$-adagokra mért nagyobb termésszintekben is kimutatható.

Az eredményekből kitünik, hogy a növényállomány igényét nem meghaladó Nadag hatására is nőtt a talajaggregátumok stabilitása. Az éppen megfelelő nitrogénszint a csak mütrágya-kezelésben részesült, valamint a szármaradvány+zöldtrágya visszaforgatással kiegészített mütrágya-kezelésben az N2 adag $\left(140 \mathrm{~kg} \cdot \mathrm{ha}^{-1} \mathrm{~N}\right)$, míg az istállótrágyával kiegészített mütrágya-kezelésben feltehetően az istállótrágya tápanyaghatásának köszönhetően az $\mathrm{N} 1$ adag $\left(70 \mathrm{~kg} \cdot \mathrm{ha}^{-1} \mathrm{~N}\right)$ volt. A szárleszántással kiegészített mütrágya-kezelésekben, a nagyobb N-adagok (N2-N3-N4) mellett az elővetemény által visszahagyott növényi maradványok stabilitásra gyakorolt, másik szervestrágyázási változatokhoz (NPK, NPK+IST) viszonyított, kedvező hatása kimutatható.

Ennek magyarázata lehet a talajba juttatott nagyobb mennyiségü szerves anyag, mint potenciális szubsztrát forrás, amely az intenzívebb mikrobiális tevékenység következtében a stabilitást növelö mikrobiális eredetü kötőanyagok mennyiségét növeli. Ez a hatás az N4-es adagú kezelésben $\left(280 \mathrm{~kg} \cdot \mathrm{ha}^{-1} \mathrm{~N}\right)$ is fennáll, ugyanakkor a talajba jutó nagy mennyiségü $\mathrm{NH}_{4}{ }^{+}$ionok stabilitást csökkentő hatása ebben a kezelésben is érvényesül. Az N4 kezelésben tehát a mért aggregátum-stabilitás értékek jelentősen elmaradnak az N2 és N3 kezelésekben mért értékekhez viszonyítva.

Eredményeink igazolták, hogy a szántóföldi növénytermesztésben az okszerü szervesanyag-gazdálkodás mellett folytatott szakszerü mütrágya-használat talajállapotra gyakorolt hatása kedvező. A nagy $\mathrm{N}$-adagok hatására az aggregátumok stabili- 
tása ugyanakkor csökkent, ami több tényezővel is magyarázható. A kísérletben alkalmazott nagyobb $\mathrm{N}$-adagok hatására a talaj $\mathrm{pH}$-ja kismértékben csökkent, így a $\mathrm{H}^{+}$koncentráció növekedésének stabilitáscsökkentő hatása érvényesülhetett.

JAGADAMMA és munkatársai (2008) is hasonló eredményre jutottak, amikor 23 éves tartamkísérletből származó talajminták aggregátum-stabilitását vizsgálva a növekvő $\mathrm{N}$-adagokkal folyamatosan csökkenő pH-t, és csökkenő talajstabilitás értékeket mértek. A vegetációs idő elején a Pétisó ammónium-nitrát hatóanyagából származó ammóniumionok párhuzamosan lejátszódó nitrifikációja miatt protonok $\left(\mathrm{H}^{+}\right)$szabadulnak fel a talajoldatban, tovább erősítve a szerkezeti stabilitást csökkentő folyamatokat (MENGEL \& KIRKBY, 2001). Az N-mütrágyaadagok növelésével a monovalens $\mathrm{NH}_{4}{ }^{+}$koncentrációja is megnövekedhetett a talajban. A monovalens ionok túlsúlya peptizációhoz, ezáltal a talajszerkezet romlásához vezet, amely a stabilitás értékek csökkenésében nyilvánul meg. A magasabb N-adagú kezelésben mérhető stabilitáscsökkenést ez a hatás is okozhatja.

A légszáraz állapotban tárolás hatására a szervestrágya-kiegészítések változatai, ill. az N0-N1-N3-N4 kezelésekben bekövetkező stabilitásnövekedés a mikrobiális kötőanyagok lebomlásával és a fizikai kötőerők jelentőségének növekedésével jól magyarázható és a szakirodalomból ismert jelenség (KEMPER \& ROSENAU 1984). Ugyanakkor az N2 kezelésekben megjelenő stabilitáscsökkenés a jelenlegi vizsgálati eredmények alapján nem magyarázható kellő bizonyossággal. Erre irányuló vizsgálatainkat más időpontban vett mintákon folytatjuk. Jelenlegi feltételezéseink szerint az aktív mikrobiális tevékenység hatására a fizikai kötőerők érvényesülését meghatározó körülmények megváltoznk. Ilyen hatása lehet a mikrobiális biomassza tárolás során elhalt alkotóinak is.

\section{Összefoglalás}

A talajok aggregátum-stabilitásának ismerete kulcsfontosságú a talajtermékenység fenntartásának és növelésének hatékony kivitelezése, valamint a talajok védelme szempontjából.

A talajaggregátumok kialakulása és végső soron a stabilitása is jórészt a szerves anyagok mennyiségének és minőségének függvénye. Találunk közöttük állandó, cementáló jellegủ anyagokat, ill. átmeneti jellegủ kötőanyagokat is. Mivel a talajok különböző mértékben tartalmazzák ezen anyagokat, és azok különböző ideig hatnak az aggregátumok szerkezetének stabilitására, indokolt lehet különbözö szervesanyag-kiegészítésủ hosszú távú tartamkísérletek mintázása az aggregátumstabilitás értékek meghatározására.A tartamkísérletek bázisán már korábban is végeztünk a talaj agronómiai szerkezetére és szerkezeti stabilitásra irányuló vizsgálatokat. Ezekre alapozottan új tartamkísérleti parcellák vizsgálatával folytattuk aggregátum stabilitás vizsgálatainkat a növekvő adagú mütrágyázás és a különböző formájú szerves anyag visszapótlású kezelésekben.

Vizsgálatainkban a vízálló aggregátumok százalékos arányát határoztuk meg (Water-stable aggregates, WSA) egy Eijkelkamp (Hollandia) nedves szita segítsé- 
gével. Vizsgálatainkhoz az 1-2 mm közötti talajfrakciót használtuk. A méréseket 250 mikronos szitákon végeztük.

A mintavétel után két héttel végzett vizsgálatok eredményeiből megállapítottuk, hogy a szervestrágya-kiegészítések közül a szár+zöldtrágya leszántás adta a legnagyobb stabilitás értéket. A N-adagok közül pedig a $140 \mathrm{~kg} \cdot \mathrm{ha}^{-1}$ kezelésben mértük a legnagyobb értéket. Utóbbi szignifikánsan nagyobbnak bizonyult minden más Nkezelésénél. A kombinációs hatások vizsgálatánál a szárleszántásos változat 140 $\mathrm{kg} \cdot \mathrm{ha}^{-1}$-os nitrogénadag melletti stabilitás értéke több mint kétszerese volt a nem szervestrágya-kiegészítésủ kontroll N-parcellákénak.

A mintavétel után három hónappal végzett stabilitásvizsgálat eredményei alapján a trágyázási változatok makroaggregátum-stabilitás értékei kiegyenlítődtek. Az $\mathrm{N}$-adagok hatását vizsgálva azonban a korábban legnagyobb stabilitású $140 \mathrm{~kg} \cdot \mathrm{ha}^{-1}$ os N-kezelés adta a legkisebb értéket. A két időpont eredményeit összehasonlítva megállapítható, hogy a stabilitás értékek minden trágyázási változatban és a $140 \cdot \mathrm{kg}$ ha $^{-1}$-os $\mathrm{N}$-adag kivételével minden N-kezelésben jelentősen növekedtek.

Kulcsszavak: agrregátum-stabilitás, tartamkísérletek, szervestrágya-kiegészítések, N-trágyázás, talajfizika

\section{Irodalom}

Alvaro-Fuentes, J., Arrue, J. L., Cantero-Martinez, C. \& Lopez, M. V., 2008. Aggregate breakdown during tillage in a Mediterranean loamy soil. Soil Tillage Res. 101. 62-68.

AMEZKETA, E., 1999. Soil aggregate stability: a review. Journal of Sustainable Agriculture 14. (2-3) 83-151.

ANDRUSChKEWITSCH, R., Koch, H-J. \& LuDwiG, B., 2014. Effect of long-term tillage treatments on the temporal dynamics of water-stable aggregates and on macroaggregate turnover at three German sites. Geoderma. 217-218. 57-64.

Annabi, M., Le Bissonnais, Y., Le Villio-Poitrenaud, M. \& Houot, S., 2011. Improvement of soil aggregate stability by repeated applications of organic amendments to a cultivated silty loam soil. Agriculture, Ecosystems and Environment. 144. (2011) 382-389.

Aoyama, M., Angers, D.A. \& N'DayegamiYe, A., 1999. Particulate and mineralassociated organic matter in water-stable aggregates as affected by mineral fertilizer and manure applications. Can. J. Soil Sci. 79. 295-302.

ARMSTRONG, A. S. B. \& TANTON, T. W., 1992. Gypsum applications to aggregated saline sodic clay topsoils. J. Soil Sci. 43. 249-260.

ARYA, L. M. \& BlAKE, G. R., 1972. Stabilization of newly formed soil aggregates. Agron. J. 64. 177-180.

Barbera, V., Poma, I., Gristina, L., Novara, A. \& Egli, M., 2012. Long-term cropping systems and tillage management effects on soil organic carbon stock and steady state level of C sequestration rates in a semiarid environment. Land Degrad. Environ. 23. 82-91. 
BArRal, M.T., Arias, M. \& GUERIF, J., 1998. Effects of iron and organic matter on the porosity and structural stability of soil aggregates. Soil Tillage Res. 46. 261-272.

BARTLETT, R., \& JAMES, B., 1980. Studying dried, stored soil samples-some pitfalls. Soil Science Society of America Journal. 44. (4) 721-724.

Bast, A., Wilcke,W., Graf, F., LÜScher, P. \& GÄrtner, H., 2014. The use of mycorrhiza for ecoengineering measures in steep alpine environments: effects on soil aggregate formation and fine-root development. Earth Surf. Process. Landf. 39. 1753-1763.

Bast, A.B., Wilcke, W., Graf, F., LÜSChER, P. \& GÄrtner, H., 2015. Simplified and rapid technique to determine an aggregate stability coefficient in coarse grained soils. Catena. 127. 170-176.

BAVER, L.D., GARDNER, W.H. \& GARDNER, W.R., 1972. Soil Physics, $4^{\text {th }}$ ed. John Wiley. New York.

Blake, G. R. \& GILMAN, R. D., 1970. Thixotropic changes with ageing of synthetic soil aggregates. Soil Sci. Soc. Am. Proc. 34. 561-564.

Blanco-Moure, N., Moret-Fernández, D. \& López, M. V., 2012. Dynamics of aggregate destabilization by water in soils under long-term conservation tillage in semiarid Spain. Catena. 99. 34-41.

BoiX-Fayos, C., CALvo-Cases, A. \& Imeson, A.C., 2001. Influence of soil properties on the aggregation of some Mediterranean soils and the use of aggregate size and stability as land degradation indicators. Catena. 44. 47-67.

BRyAn, R.B., GOVERS, G. \& POESEN, J., 1989. The concept of soil erodibility and some problems of assessment and application. Catena 16. 393-412.

Broersma, K., Robertson, J. A. \& Chanasyk, D. S., 1997. The effects of diverse cropping systems on aggregation of a Luvisolic soil in the Peace River region. Can. J. Soil Sci. 77. 323-329.

Brown, G. G., Barois, I. \& LAvelle, P., 2000. Regulation of soil organic matter dynamics and microbial activity in the drilosphere and the role of interactions with other edaphic functional domains. Eur. J. Soil Biol. 36. 177-198.

Caron, J., KAY, B.D. \& Perfect, E., 1992. Short-term decrease in soil structure stability following bromegrass establishment on a clay loam soil. Plant Soil 145. 121-130.

CHAN, K. Y. \& HeEnAN, D. P., 1996. The influence of crop rotation on soil structure and soil physical properties under conventional tillage. Soil Tillage Res. 37. 113-125.

Chan, K. Y. \& HeEnAN, D. P., 1999. Lime-induced loss of soil organic carbon and effect on aggregate stability. Soil Sci. Soc. Am. J. 63. 1841-1844.

CHENU, C., 2000. Organic matter influence on clay wettability and soil aggregate stability. Soil Science Society of America Journal 64. 1479-1486.

Chivenge, P., Vanlauwe, B., Gentile, R. \& Six, J., 2011. Organic resource quality influences short-term aggregate dynamics and soil organic carbon and nitrogen accumulation. Soil Biol. Biochem. 43. 657-666.

Cosentino, D., Le Bissonnais, Y. \& Chenu, C., 2006. Aggregate stability and microbial community dynamics under drying-wetting cycles in a silt loam soil. Soil Biology \& Biochemistry 38. 2053-2062.

DAlAl, R. C. \& BRIDGE, B. J., 1996. Aggregation and organic matter storage in subhumid and semi-arid soils. In: Structure and Organic Matter Storage in 
Agricultural Soils. (Eds.: CARTER, M. R. \& StEWART, B. A.) 263-307. CRC Press. Boca Raton, FL.

DiaZ, E., RoldÁn, A., LAX, A. \& Albaladejo, J., 1994. Formation of stable aggregates in degraded soil by amendment with urban refuse and peat. Geoderma. 63. 277288.

DUIKER, S. W. \& LAL, R., 1999. Crop residue and tillage effects on carbon sequestration in a Luvisol in central Ohio. Soil Tillage Res. 52. 73-81.

DvORACSEK M., 1957. V/7. fejezet: A talajmorzsák vízállóságának mérése. In: Talajfizika és talajkolloidika. (Di GLÉRIA J., KLIMES-SZMIK A. \& DVORACSEK M.) 449465. Akadémiai Kiadó. Budapest.

FACELLI, E. \& FACELLI, J. M., 2002. Soil phosphorus heterogeneity and mycorrhizal symbiosis regulate plant intra-specific competition and size distribution. Oecologia 133. $54-61$.

HAYNES, R. J. \& BEARE, M. H., 1997. Influence of six crop species on aggregate stability and some labile organic matter fractions. Soil Biol. Biochem. 29. 16471653.

HAYNES, R. J. \& NAIDU, R., 1998. Influence of lime, fertilizer and manure applications on soil organic matter content and soil physical conditions: a review. Nutr. Cycl. Agroecosyst. 51. 123-137.

Huisz, A., 2012. A talajszerkezet és a szervesanyag-megoszlás változásainak jellemzése új módszerekkel művelési tartamkísérletben. PhD-értekezés. Debrecen.

IGWE, C. A., ZAREI, M. \& STAHR, K., 2009. Colloidal stability in some tropical soils of southeastern Nigeria as affected by iron and aluminium oxides. Catena. 77. 232237.

JagadAmma, S., LAL, R., Hoeft, R. G., NAfZiger, E. D. \& AdeE, E. A., 2008. Nitrogen fertilization and cropping system impacts on soil properties and their relationship to crop yield in the central Corn Belt, USA. Soil \& Tillage Research 98. (2008) $120-129$.

JASTROW, J. D., 1996. Soil aggregate formation and the accrual of particulate and mineral-associated organic matter. Soil Biol. Biochem. 28. 665-676.

JOZEFACIUK, G. \& CZACHOR, H., 2014. Impact of organic matter, iron oxides, alumina, silica and drying on mechanical and water stability of artificial soil aggregates. Assessment of new method to study water stability. Geoderma. 221-222. (2014) $1-10$.

KAzÓ B., 1958. Homokfelszín megkötés hazai gyártmányú "Solakrol"-lal. Agrokémia és Talajtan. 7. 141-150.

KAY, B. D., 1998. Soil structure and organic carbon: a review. In: Soil Processes and the Carbon Cycle. Eds.: (Lal, R., Kimble, J. ., Follett, R. F. \& Stewart, B. A.) 169-197. CRC Press. Boca Raton.

KAY, B. D. \& ANGers, D. A., 1999. Structure. In: Handbook of Soil Science. (Ed.: SUMNER, M. E.) 229-276. CRC press, Boca Raton.

KEMPER, W. D. \& KoCH, E. J., 1966. Aggregate stability of soils from western portions of the United States and Canada. U.S. Dep. Agric. Tech. Bull., 1355.

Kemper, W. D. \& Rosenau, R. C., 1986. Aggregate stability and size distribution. In Methods of Soil Analysis: Part 1. Physical and Mineralogical Methods, 2nd Ed.; Klute, A., Ed.; ASA-SSSA: Madison, WI. 425- 442. 
Kemper, W. D. \& Rosenau, R. C., 1984. Soil cohesion as affected by time and water content. Soil Sci. Soc. Am. J. 48. 1001-1006.

LAdD, J. N., Foster, R. C., NANNiPieri, P. \& OAdes, J. M., 1996. Soil structure and biological activity. In: Soil Biochemistry, vol. 9. (Eds.: StotzKy, G. \& BollaG, J.M.) 23-78. Marcel Dekker. New York.

LAYton, J. B., Skidmore, E. L. \& ThOMPSON, C. A., 1993. Winter-associated changes in dry-soil aggregation as influenced by management. Soil Sci. Soc. Am. J. 57. 1568-1572.

LE BissonNAIS, Y., 1996. Aggregate stability and assessment of soil crustability and erodibility: I. Theory and methodology. European Journal of Soil Science. 47. 425-431.

Le Bissonnais, Y., Blavet, D., De Noni, G., Laurent, J. Y., Asseline, J. \& Chenu, C., 2007. Erodibility of Mediterranean vineyard soils: relevant aggregate stability methods and significant soil variables. European Journal of Soil Science. 58. 188195.

LiU, A., MA, B. L. \& BomKe, A. A., 2005. Effects of cover crops on soil aggregate stability, total organic carbon, and polysaccharides. Soil Science Society of America Journal. 69. 2041-2048.

Long, P., Sui, P., GaO, W., Wang, B., Huang, J., Yan, P., Zou, J., Yan, L. \& Chen, Y., 2015. Aggregate stability and associated $\mathrm{C}$ and $\mathrm{N}$ in a silty loam soil as affected by organic material inputs. Journal of Integrative Agriculture 2015. 14. (4) $774-787$.

Martens, D. A., 2000. Plant residue biochemistry regulates soil carbon cycling and carbon sequestration. Soil Biol. Biochem. 32. 361-369.

MaZURAK, A. P., 1950. Aggregation of clay separates from bentonite, kaolinite and a hydrous mica soil. Soil Sci. Soc. Amer. Proc. 15. 18-24.

Mbagwu, J. S. C., 1989. Influence of Cattle-Feedlot Manure on Aggregate Stability, Plastic Limit and Water Relations of Three Soils in North-Central Italy. Biological Wastes. 28. 257-269.

Mengel, K., \& KIRKBY, E. A., 2001. Principles of Plant Nutrition. Kluwer Acamdemic Publishers. Dordrect, The Netherlands.

Nimmo, J. R., 2013. Aggregation: Physical Aspects, Reference Module in Earth Systems and Environmental Sciences. Elsevier. doi: 10.1016/B978-0-12-409548-9.050879.

OAdes, J. M. \& Waters, A. G., 1991. Aggregate hierarchy in soils. Aust. J. Soil Res. 29. 815-828.

OADES, J. M., 1993. The role of biology in the formation, stabilization and degradation of soil structure. Geoderma. 56. 377-400.

Paul, B. K., Vanlauwe, B., Ayuke, F., Gassner, A., Hoogmoed, M., Hurisso, T. T., Koala, S., Lelei, D., Ndabamenye, T., SiX, J. \& Pulleman, J. J., 2013. Mediumterm impact of tillage and residue management on soil aggregate stability, soil carbon and crop productivity. Agriculture, Ecosystems and Environment. 164. 14 22.

Pare, T., Dinel, H., Moulin, A. P. \& Townley-Smith, L., 1999. Organic matter quality and structure stability of a Black Chernozemic soil under different manure and tillage practices. Geoderma. 91. 311-326. 
Peng, X. H., Horn, R., Zhang, B. \& ZhaO, Q. G., 2004. Mechanisms of soil vulnerability to compaction of homogenized and recompacted Ultisols. Soil and Tillage Research. 76. (2) 125-137.

Piccolo, A., Pietramellara, G. \& Mbagwu, J. S. C., 1997. Use of humic substances as soil conditioners to increase aggregate stability. Geoderma. 75. 267-277.

Rillig, M. C., Wright, S. F. \& Eviner, V. T., 2002. The role of arbuscular mycorrhizal fungi and glomalin in soil aggregation: comparing effects of five plant species. Plant Soil. 238. 325-333.

Roberson, E., SARIG, S., Shennan, C. \& Firestone, M. 1995. Nutritional management of microbial polysaccharide production and aggregation in an agricultural soil. Soil Sci. Soc. Am. J. 59. 1587-1594.

SaHA, D., Kukal, S. S. \& Sharma, S., 2011. Landuse impacts on SOC fractions and aggregate stability in typic ustochrepts of Northwest India. Plant Soil. 339. 457470.

Schlecht-Pietsch, S., Wagner, U. \& Anderson, T. H., 1994. Changes in composition of soil polysaccharides and aggregate stability after carbon amendments to different textured soils. Appl. Soil Ecol. 1. 145-154.

SCHUTTER, M. E. \& Dick, R. P., 2002. Microbial community profiles and activities among aggregates of winter fallow and cover-cropped soil. Soil Sci. Soc. Am. J. 66. $142-153$.

Schweikle, U., Blake, G. R. \& AryA, L. M., 1974. Matric suction and stability changes in sheared soil. Trans. 10th Int. Congr. Soil Sci. 1. 187-193.

ShaO-Shan, A., DARBoux, F. \& CHENG, M., 2013. Revegetation as an efficient means of increasing soil aggregate stability on the Loess Plateau (China). Geoderma. 209-210. 75-85.

Siddiky, M. R. K., Kohler, J., Cosme, M. \& Rillig, M. C., 2012. Soil biota effects on soil structure: interactions between arbuscular mycorrhizal fungal mycelium and collembola. Soil Biol. Biochem. 50. 33-39.

Six, J., Elliott, E. T. \& Paustian, K., 1999. Aggregate and soil organic matter dynamics under conventional and no-tillage systems. Soil Sci. Soc. Am. J. 63. 1350-1358.

Six, J., Elliott, E. T. \& Paustian, K., 2000. Soil macroaggregate turnover and microaggregate formation: a mechanism for $\mathrm{C}$ sequestration under no-tillage agriculture. Soil Biol. Biochem. 32. 2099-2103.

Spaccini, R., Mbagwu, J. S. C., Igwe, C. A., Conte, P. \& Piccolo, A., 2004. Carbohydrates and aggregation in lowlands soils of Nigeria as influenced by organic inputs. Soil \& Tillage Research. 75. 161-172.

Thomsen, I. K., Schjonning, P., Olesen, J. E. \& Christensen, B. T., 1999. Turnover of organic matter in differently textured soils: II. Microbial activity as influenced by soil water regimes. Geoderma. 89. 199-218.

Thomsen, I. K., Schjonning, P., Olesen, J. E. \& Christensen, B. T., 2003. C and N turnover in structurally intact soils of different texture. Soil Biol. Biochem. 35. 765-774.

Tisdale, S. L., Nelson, W. L. \& Beaton, J. D. 1993. Soil fertility and soil fertilizers. Macmillan Publishing Co. N. Y.

TISDALL, J. M., 1991. Fungal hyphae and structural stability of soil. Austr. J. Soil Res. 29. 729-743. 
TISDALL, J. M., 1996. Formation of soil aggregates and accumulation of soil organic matter. In: Structure and Organic Matter Storage in Agricultural Soils. (Eds.: Carter, M. R. \& Stewart, B. A.) 57-96. CRC Press. Boca Raton, FL.

Traoré, O., Groleau-Renaud, V., Plantureux, S. \& Tubeileh, V., 2000. Effect of root mucilage and modelled root exudates on soil structure. European Journal of Soil Science. 51. 575-581.

Utomo, W. H. \& DeXteR, A. R., 1981. Effect of ageing on compression resistance and water stability of soil aggregates disturbed by tillage. Soil Tillage Res. 1. 127-137.

YODER, R. E., 1936. A direct method of aggregate analysis of soils and a study of physical nature of erosion losses. J. Am. Soc. Agron. 28. 337-351.

Villar, M. C., Petrikova, V., Díaz-Raviña, M. \& Carballas, T., 2004. Changes in soil microbial biomass and aggregate stability following burning and soil rehabilitation. Geoderma 122. (2004) 73-82.

Wang, W., Chen, W., Wang, K., Xie, X., Yin, C. \& Chen, A. 2011. Effects of LongTerm Fertilization on the Distribution of Carbon, Nitrogen and Phosphorus in Water-Stable Aggregates in Paddy Soil. Agricultural Sciences in China. 10. (12) 1932-1940.

Whalen, J. K. \& CHANG, C., 2002. Macroaggregate characteristics in cultivated soils after 25 years annual manure applications. Soil Sci. Soc. Am. J. 66. 1637-1647.

Winsome, T. \& MCColl, J. G., 1998. Changes in chemistry and aggregation of a California forest soil worked by the earthworm Argilophilus papillifer Eisen (Megascolecidae). Soil Biol. Biochem. 30. 1677-1687.

Wright, S., Starr, J. \& Paltineau, I., 1999. Changes in aggregate stability and concentration of glomalin during tillate management transition. Soil Sci. Soc. Am. J. 63. 1825-1829.

ZALleR, J. G. \& KÖPKE, U., 2004. Effects of traditional and biodynamic farmyard manure amendment on yields, soil chemical, biochemical and biological properties in a long-term field experiment. Biol. Fertil. Soils 40. 222-229.

ZhANG, X. C. \& Norton, L. D., 2002. Effect of exchangeable Mg on saturated hydraulic conductivity, disaggregation and clay dispersion of disturbed soils. J. Hydrol. 260. 194-205.

Érkezett: 2015. február 15. 


\title{
Long-term effect of organic and mineral fertilization on the stability of soil aggregates on a brown forest soil
}

\author{
A. DunAI and Z. TÓTH \\ Department of Crop Production and Soil Science, University of Pannonia, Georgikon Faculty, \\ Keszthely
}

\begin{abstract}
Summary
The information about the stability of soil aggregates is essential either to sustain and increase soil fertility and productivity or to conserve soil.

The status of soil structure, the size of soil particles, as well as their resistance against water and the physical disturbance caused by tillage equipments are good indicators of agronomic value and fertility of soil (,agronomic soil structure”). Any change in soil structure resulting in the modification of the ratios between the volumes of different pore sizes consequently the characteristics of the modified structure of pore system will be also changed. This change in the characteristics and function of pore system influences water and air management characteristics of soil by means of which influences many factors relating to soil fertility.

Formation and stability of aggregates mostly depends on the amount and quality of organic matters. Amongst them there are permanent cementing materials as well as temporary binding agents. While soils contain of these materials in different rates, and their effects last for different time to the stability of aggregates, it can be justified to sample long-term field experiments provided with different organic matter supplies, and the examination of these samples in several times to determine the stability of aggregates at the initial stage and the changing of the stability with the time.

On the basis of field experiments - which also provide the background of this measurement - we've made investigations aimed to determination of the agronomic soil structure and structural stability, which were proved significant differences between the effect of different crops and different composition of crop rotations. Base on our previous examinations we continued our aggregate stability investigations with the treatments obtained by increasing rates of inorganic fertilizers and different formed organic matter replacement.

During our investigations we've determined the percental rate of water-stable aggregates (WSA) with an Eijkelkamp wet sieving apparatus (The Netherlands). We've used the 1-2 mm soil fraction, the measurements were made with 250 micron sieves. The sample materials of the investigation were proved by the plots of a long-term field experiment with different organic matter supplies and $\mathrm{N}$-fertilizer rates. The soil samples were collected from the ploughed layer on May 2014. The macroaggregate stability was measured after two weeks and three months of the sampling to investigate the effects of air-dried storage to the aggregate stability.

From the results of the examinations made after two weeks of the sampling it can be concluded that from the organic matter supplies, the NPK+Straw + Green manure treatments showed the highest aggregate stability values, and from the N-rates, the 140 $\mathrm{kg} \cdot \mathrm{ha}^{-1}$ dose resulted the highest values, the latter was significantly higher than the
\end{abstract}


measured stabilities by any other N-rate values. By the examination of the combination effects, the aggregate stability values by NPK+Straw+Green manure plots at $140 \mathrm{~kg} \cdot \mathrm{ha}^{-1}$ $\mathrm{N}$-dose were more than the double as the stability values measured by the plots treated with only $\mathrm{P}$ and $\mathrm{K}$ inorganic fertilizers (without $\mathrm{N}$-supply).

Based on the stability measurements made after three months of the sampling the macroaggregate stability values were equalized. However, during the investigation of the N-rates, $140 \mathrm{~kg} \cdot \mathrm{ha}^{-1} \mathrm{~N}$-dose - which resulted the highest values in the two weeksexaminations - resulted the lowest stability values by the three months measuring. Compared of the values of the two different time measuring it can be concluded that the stability values were increased in all types of organic matter supplies and N-rates, with the exception of $140 \mathrm{~kg} \cdot \mathrm{ha}^{-1}$.

Table 1. Aggregate stability values originated from the two weeks measurements by organic matter supplies and N-supply. (1) Organic matter supplies. (2) N-dose $\mathrm{kg} \cdot \mathrm{ha}^{-1}$. a) NPK-only. b) NPK+farmyard manure. c) NPK+straw+green manure.

Table 2. Aggregate stability values originated from the three months measurements by organic matter supplies and N-supply. (1) Organic matter supplies. (2) N-dose $\mathrm{kg} \cdot \mathrm{ha}^{-1}$. a) NPK-only. b) NPK+farmyard manure. c) NPK+straw+green manure.

Figure 1. Aggregate stability values (\%) originated from the two weeks measurements (A) by organic matter supplies in average of N-supply; (B) by N-supply in average of organic matter supplies. Different letters mean significant differencies between the marked factors based on LSD post-hoc test at $\mathrm{P}<5 \%$

Figure 2. Aggregate stability values (\%) originated from the three months measurements (A) by organic matter supplies in average of N-supply; (B) by N-supply in average of organic matter supplies. Different letters mean significant differencies between the marked factors based on LSD post-hoc test at $\mathrm{P}<5 \%$

Figure 3. Changing of the measured stability values between the measuring time by organic matter supplies in average of $\mathrm{N}$-supply.

Figure 4. Changing of the measured stability values between the measuring time by $\mathrm{N}$-supply in average of organic matter supplies. 